\title{
Bioactivity of Sweet Flag (Acorus calamus Linnaeus) Essential Oils Against Spodoptera litura Fabricius (Lepidoptera: Noctuidae)
}

Dewi Melani ${ }^{1,3 *}$, Toto Himawan ${ }^{2}$, Aminudin Afandhi ${ }^{2}$

\author{
${ }^{1}$ Post Graduate Program, Faculty of Agriculture, Brawijaya University, Malang, Indonesia \\ ${ }^{2}$ Department Plant Pest and Disease, Faculty of Agriculture, Brawijaya University, Malang, Indonesia \\ ${ }^{3}$ National Agricultural Training Center of Ketindan, Ministry of Agriculture, Malang, Indonesia
}

\begin{abstract}
The study aims to determine the chemical compounds, toxicity, and antifeedant activity of sweet flag (Acorus calamus) essential oils against third instar larvae of Spodoptera litura. The study was conducted using a completely randomized design (CRD) using various concentration of the essential oils $\left(10^{3}, 2 \times 10^{3}, 3 \times 10^{3}, 4 \times 10^{3}, 5\right.$ $\times 10^{3} \mathrm{ppm}$ ). Mortality and antifeedant activity was observed 24 hours after treatment. Toxicity and antifeedant activity values were $92.5 \%$ and $79.3 \%$, respectively, with an $\mathrm{LC}_{50}$ value $586.96 \mathrm{ppm}$. Gas chromatography-mass spectrometry analysis showed that essential oil of $A$. calamus consists of five chemical compounds: methyl isoeugenol, 3.9-decadien-ol-1,3-methyl-6-(1-methylethenyl), 4-pentyl-1-(4propylcyclohexyl)1cyclohexene, $\gamma$-asarone and $\beta$ asarone.
\end{abstract}

Keywords: Acorus calamus, antifeedant, essential oils, mortality, Spodoptera litura

\section{INTRODUCTION}

Asian armyworm (Spodoptera litura) is a polyphagous insect that is abundant in tropical countries. It attttacks more than 120 species of cultivated crops at vari ous phases of growth causing serious yield loss [1]. The spread of $S$. litura in Indonesia covered 22 provinces with an area of attack reaching $11.163 \mathrm{ha} /$ year [2].

Secondary metabolites of plants or botanical insecticides can be used to $S$. litura. There are over 2400 species of plants that are potential sources of bioinsecticide [3]. Bioinsecticides provide benefits for both environment and agriculture product consumers. For example, the application of botanical insecticide can cause mortality at the time of application and residue left behind will immediately decompose, so the plant is safe for consumption. Botanical insecticides also can kill or disturb insect pests through separately or sinergistically combination, their works very specific like disturbing the development of eggs, larvae, and pupae, inhibits change of skin, disrupting the communication of insect, inhibiting reproduction of female insects, reducing

${ }^{*}$ Corresponding author:

Dewi Melani

National Agricultural Training Center of Ketindan,

Ministry of Agriculture

Jalan Ketindan No. 1 Lawang, Malang 65214, Indonesia

E-mail: melanidewi85@gmail.com appetite (antifeedan), block the ability of eating insects and repelent insects [4]. Botanical insecticide can even inhibit insects already resistant to active ingredients from conventional pesticides because there are different compounds in biopesticides that act simultaneously [5].

Sweet flag (Acorus calamus) rhizome, a member of family Acoraceae, contains saponins, flavonoids and essential oils. A. calamus essential oil has been documented to have insect-repellent, antifeedant and chemosterilant activities [6-7]. Its essential oil is toxic to third-instar larvae of Plutella xylostella [8] and has an antifeedant activity against the third instar larvae of S. litura and Peridroma saucia [9]. A. calamus essential oil exhibits larvicidal activity against third instar larvae of Aedes aegypti with $\mathrm{LC}_{50}$ value $150 \mathrm{ppm}$ [10], and early fourth instar larvae of Culex quinquefasciatus with $\mathrm{LC}_{50}$ value $63.4 \mathrm{~mL} / \mathrm{L}$ [11]. Hexane and methanolic fraction of $A$. calamus rhizome also has termiticidal activity against Coptotermes curvignathus [12]. Given the potential of A.calamus as a candidate

\section{How to cite:}

Melani D, Himawan T, Afandhi A (2016) Bioactivity of sweet

flag (Acorus calamus Linnaeus) Essential Oils Against

Spodoptera litura Fabricius (Lepidoptera: Noctuidae). J. Trop.

Life. Science 6 (2): $86-90$. 
biopesticide, in this paper, we analyzed the bioactivity of its essential oil against $S$. litura larvae and characterized the bioactive components.

\section{MATERIALS AND METHODS}

\section{Plant materials}

The rhizome of sweet flag $(A$. calamus) were collected from Semambung Village, Purwodadi District, Pasuruan. The rhizomes were around 1 year old and had the dimensions: 5-10 cm (length) and 1-2 cm (diameter).

\section{Essential oil distillation and gas chromatography-mass spectrometry (GC-MS) Analysis}

The rhizomes were washed after collection to remove dust and other contaminants, sliced and dried under a shade at room temperature $\left(30 \pm 2^{\circ} \mathrm{C}\right)$ for 4 days. The plant material was hydro-distilled for 6 hours. The oil obtained was desiccated with anhydrous $\mathrm{Na}_{2} \mathrm{SO}_{4}$ to remove excess water and stored in a refrigerator at $4^{\circ} \mathrm{C}$ prior to chemical analyzed and bioassay.

The volatile constituents were analyzed by gas chromatography- mass spectrometry (GC-MS) using a Shimadzu QP 2010S. The parameters used were: temperature range, $80-250{ }^{\circ} \mathrm{C}$, rate of temperature increase, $10^{\circ} \mathrm{C}$; helium carrier gas pressure, $100 \mathrm{kPa}$; the total injection rate, $588.8 \mathrm{~mL} / \mathrm{min}$; and split ratio, 1:400. The identification of the components was based on a comparison of their mass spectra with those of WILEY8.LIB. Relative percentages of the individual components of the essential oil were obtained by averaging the GC-FID peak area percentages [11].

\section{Rearing of Spodoptera litura}

Egg mass of $S$. litura was collected from Indonesian Sweetener and Fiber Crops Research Institute (ISRFI), Malang. The eggs were reared and allowed to hatch under laboratory conditions $28^{\circ} \mathrm{C}$ and $74 \%$ relative humidity. After hatching, the neonate larvae were fed castor leaves (Ricinus communis) in the laboratory until third instar larvae emerged [13].

\section{Larvicidal activity}

Larvacidal activity of the essential oil was determined using the leaf dipping method [14]. The experiment was conducted at laboratory temperature of $28^{\circ} \mathrm{C}$ and $74 \%$ relative humidity.

The stock solution was prepared by dissolving the essential oil with Tween 80 as an emulsifier. A small square disc $\left(4 \times 4 \mathrm{~cm}^{2}\right)$ was cut from the fresh castor leaves. The leaves were dipped for 10 seconds in various concentrations of the essential oil $\left(10^{3}, 2 \times 10^{3}, 3 \times\right.$ $\left.10^{3}, 4 \times 10^{3}, 5 \times 10^{3} \mathrm{ppm}\right)$ and then air-dried [15]. The assay was performed in a humidified jar $(11 \mathrm{~cm}$ (diameter) $\times 20 \mathrm{~cm}($ high)). To avoid early drying of the leaf disc, moist filter paper was placed inside the jar. Twenty early third-instar larvae $S$. litura, that have been pre-starved for 6 hours were introduced to the treated and control leaf disc. The larvae were continously maintained on untreated fresh castor leaves for 24 hours. Four replicates with one control were used for every treatment concentration tested. Larval mortality was calculated after 24 hours until 96 hours. The lethal concentration $\mathrm{LC}_{50}$ were calculated by probit analysis. Percentage larval mortality was calculated using formula:

$$
\frac{\text { Number of dead larvae }}{\text { Number of treated larvae }} \times 100 \%
$$

\section{Antifeedant activity}

Antifeedant activity was tested by no-choice leafdisc method [14]. Leaf weight consumed by the larva in the control and the treatments were determined after 24 hours until 96 hours. Four replicates with one control were maintained for each concentration. The percentage antifeedant activity was calculated by formula:

$$
1-\frac{\text { Leaves weight treatment consumed }}{\text { Leaves weight control consumed }} \times 100 \%
$$

\section{Statistical analysis}

The analysis of variance (ANOVA) was calculated using SPSS ver. 18 for Windows using level of significance $(\alpha)$ 0.05. Significant differences between treatment were determined by Duncan Multiple Range Test (DMRT). The data mortalities were corrected using Abbott's formula [16] and $\mathrm{LC}_{50}$ values were calculated using probit analysis [17].

\section{RESULTS AND DISCUSSION \\ Essential oil chemical composition}

The yield of $A$. calamus essential oil was $0.88 \%$ $(\mathrm{V} / \mathrm{W})$. The essential oil was yellow in color and has a strong aroma. GC-MS analysis of the essential oil of A. calamus rhizomes led to identify and quantify of 5 (five) components (Figure 1).

The chemical compound of GC-MS essential oils of 
Table 1. Chemical compound of sweet flag (A. calamus) essential oils

\begin{tabular}{|c|c|c|c|c|c|}
\hline Peak & Retention time (min) & Molecular formula & Estimated Name & $\begin{array}{c}\text { Molecular mass } \\
\left(M^{+}, \mathrm{g} / \mathrm{mol}\right) \\
\end{array}$ & $\begin{array}{c}\text { Relative area } \\
(\%)\end{array}$ \\
\hline 1 & 11.199 & $\mathrm{C}_{11} \mathrm{H}_{14} \mathrm{O}_{2}$ & $\begin{array}{c}\text { Benzene, } 1,2 \text { dimethoxy-4-(1-propenyl) } \\
\text { (Methyl isoeugenol) }\end{array}$ & 178 & 0.63 \\
\hline 2 & 11.845 & $\mathrm{C}_{14} \mathrm{H}_{24} \mathrm{O}$ & $\begin{array}{c}\text { 3,9-Decadien-1-Ol, 3-Methyl-6-(1- } \\
\text { Methylethenyl) }\end{array}$ & 208 & 0.05 \\
\hline 3 & 12.107 & $\mathrm{C}_{20} \mathrm{H}_{36}$ & $\begin{array}{l}\text { 4-Pentyl-1-(4-Propylcyclohexyl)-1- } \\
\text { Cyclohexene }\end{array}$ & 276 & 0.85 \\
\hline 4 & 12.711 & $\mathrm{C}_{12} \mathrm{H}_{16} \mathrm{O}_{3}$ & $\begin{array}{c}\text { 1-Allyl-2,4,5-Trimethoxy-Benzene }(\gamma- \\
\text { asarone })\end{array}$ & 208 & 0.31 \\
\hline 5 & 13.361 & $\mathrm{C}_{12} \mathrm{H}_{16} \mathrm{O}_{3}$ & $\begin{array}{c}\text { Benzene, 1,2,4-Trimethoxy-5-(1-propenyl)- } \\
\text { (Z) ( } \beta \text { - asarone) }\end{array}$ & 208 & 98.16 \\
\hline
\end{tabular}

Tabel 2. Percentage mortality of $S$. litura larvae

\begin{tabular}{|c|c|c|c|c|}
\hline \multirow[t]{2}{*}{ Treatment } & \multicolumn{4}{|c|}{ Mortality of larvae (\%) } \\
\hline & $24 H A T$ & $48 H A T$ & $72 H A T$ & 96 HAT \\
\hline (POK0) Control & $0.00 \pm 0.00^{\mathrm{a}}$ & $0.00 \pm 0.00^{\mathrm{a}}$ & $0.00 \pm 0.00^{\mathrm{a}}$ & $0.00 \pm 0.00^{\mathrm{a}}$ \\
\hline (P1K1) Essential oil $10^{3}$ & $10.00 \pm 4.08^{\mathrm{b}}$ & $35.00 \pm 7.07^{\mathrm{b}}$ & $56.25 \pm 8.53^{b}$ & $72.50 \pm 2.88^{\mathrm{b}}$ \\
\hline$(\mathrm{P} 1 \mathrm{~K} 2)$ Essential oil $2 \times 10^{3}$ & $15.00 \pm 4.08^{\mathrm{b}}$ & $41.25 \pm 4.78^{\mathrm{b}}$ & $56.25 \pm 10.30^{b}$ & $78.75 \pm 13.14^{b c}$ \\
\hline (P1K3) Essential oil $3 \times 10^{3}$ & $17.50 \pm 6.45^{\mathrm{b}}$ & $43.75 \pm 2.50^{b c}$ & $62.50 \pm 2.88^{b c}$ & $83.75 \pm 6.29^{\mathrm{cd}}$ \\
\hline (P1K4) Essential oil $4 \times 10^{3}$ & $27.50 \pm 6.45^{\mathrm{c}}$ & $51.25 \pm 7.50^{\mathrm{cd}}$ & $68.75 \pm 4.78^{\mathrm{c}}$ & $91.25 \pm 6.29^{\mathrm{d}}$ \\
\hline$(\mathrm{P} 1 \mathrm{~K} 5)$ Essential oil $5 \times 10^{3}$ & $33.75 \pm 6.29^{c}$ & $53.75 \pm 7.50^{\mathrm{d}}$ & $68.75 \pm 7.50^{\mathrm{c}}$ & $92.50 \pm 2.88^{\mathrm{d}}$ \\
\hline
\end{tabular}

Note:

- HAT: hours after treatment

- Figures followed by the same letters in the same column are not significantly different based on DMRT test $(\alpha=0.05 \%)$

Table 3. Percentage antifeedant activity of $S$. litura larvae

\begin{tabular}{|c|c|c|c|c|}
\hline \multirow[t]{2}{*}{ Treatment } & \multicolumn{4}{|c|}{ Mortality of larvae (\%) } \\
\hline & $24 H A T$ & $48 H A T$ & $72 H A T$ & $96 H A T$ \\
\hline (PoKo) Control & $0.00 \pm 0.00^{\mathrm{a}}$ & $0.00 \pm 0.00^{\mathrm{a}}$ & $0.00 \pm 0.00^{\mathrm{a}}$ & $0.00 \pm 0.00^{\mathrm{a}}$ \\
\hline (P1K1) Essential oil $10^{3}$ & $10.00 \pm 4.08^{\mathrm{b}}$ & $35.00 \pm 7.07^{\mathrm{b}}$ & $56.25 \pm 8.53^{b}$ & $72.50 \pm 2.88^{b}$ \\
\hline (P1K2) Essential oil $2 \times 10^{3}$ & $15.00 \pm 4.08^{\mathrm{b}}$ & $41.25 \pm 4.78^{\mathrm{b}}$ & $56.25 \pm 10.30^{b}$ & $78.75 \pm 13.14^{b c}$ \\
\hline$(\mathrm{P} 1 \mathrm{~K} 3)$ Essential oil $3 \times 10^{3}$ & $17.50 \pm 6.45^{\mathrm{b}}$ & $43.75 \pm 2.50^{b c}$ & $62.50 \pm 2.88^{b c}$ & $83.75 \pm 6.29^{\mathrm{cd}}$ \\
\hline (P1K4) Essential oil 4x10 & $27.50 \pm 6.45^{\mathrm{c}}$ & $51.25 \pm 7.50^{\mathrm{cd}}$ & $68.75 \pm 4.78^{c}$ & $91.25 \pm 6.29^{\mathrm{d}}$ \\
\hline$(\mathrm{P} 1 \mathrm{~K} 5)$ Essential oil $5 \times 10^{3}$ & $33.75 \pm 6.29^{c}$ & $53.75 \pm 7.50^{\mathrm{d}}$ & $68.75 \pm 7.50^{c}$ & $92.50 \pm 2.88^{\mathrm{d}}$ \\
\hline
\end{tabular}

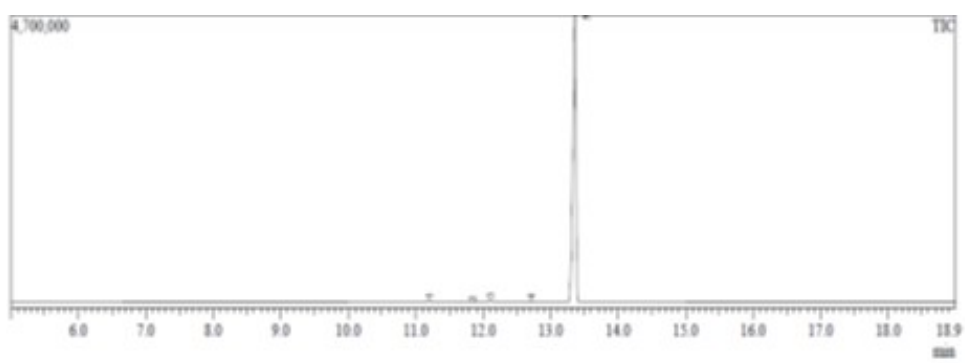

(a)

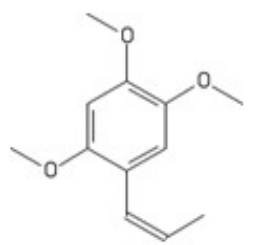

(b)

Figure 1. Chromatogram of sweet flag (A. calamus) essential oils (a). $\beta$-asarone structure (b) 
sweet flag (A. calamus) can be show in Table I. The chromatogram shows chemical compounds with the highest relative area $98.16 \%$. These are benzene, 1,2,4trimethoxy-5-(1-propenyl)- $(Z)$ or ( $\beta$-asarone) (Figure $1 b)$. There are 4 other chemical constituents that have percentage relative areas $<1 \%$.

\section{Larvacidal activity of Spodoptera litura larvae}

The application of essential oils affect led to a dosedependent increases in mortality of $S$. litura with DMRT at 5\% level (Table 2). Based on Table 2, P1K4 and $\mathrm{P} 1 \mathrm{~K} 5$ are not significally different and $\mathrm{P} 1 \mathrm{~K} 5$ shows the highest percentage mortality (92.5\%) with LC50 values of $586.96 \mathrm{ppm}$. Treated larvae exhibit both a decrease in mobility and feeding activity. The larvae have become shriveled and smaller, and the body color has changed from brown to brown-black (Figure 2b). The change in the pigments may be due to the melanization process which is a defense mechanism of the insect against foreign compound [18] Melanization is influenced by phenoloxidase that play roles in wound healing and cuticle formation [19].

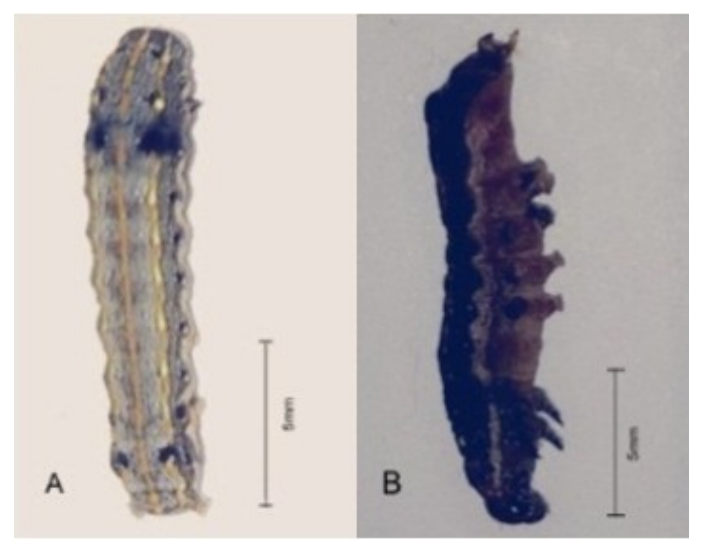

Figure 2. S. litura larvae normal (A) and after exposure by $A$. calamus essential oil (B)

Mortality of $S$. litura larvae is affected by the chemical compounds in essential oils, particularly by $\beta$ asarone (Figure 1b). $\beta$-asarone serves a contact and stomach poison [6]. $\beta$-asarone is a contact poison that penetrates the body through the cuticle layer towards hemolymph affecting the nervous system by targeting acetylcholinesterase [20]. While the acetylcholinesterase enzyme degrades acetylcholine into acetyl co-A and choline at the synapes, the build up of acetylcholine can disturb delivery system impulses to the muscle cells. The insect becomes spastic and paralyzed, and eventually dies [21]. When ingested, $\beta$-asarone can damage the insect's intestinal wall which can lead to death. $\beta$-asarone penetrates and disrupts the function of the mesenteron, a tissue layer composed of epithelial cells that absorb nutrients and secrete digestive enzymes in insects. The late-instar $S$. litura larvae treated with 500 and 1000 ppm essential oil orally have been earlier demonstrated to have abnormal hemocyte profile [22]. The cell counts of different types of hemocytes (plasmatocytes, prohemocytes, oenocytoids, spherulocytes, granular hemocytes) decreased after 4872 hours after treatment. Total hemocytes decreased 29.15 and $49.05 \%$ at 500 and 1000 ppm after 72 hours.

\section{Antifeedant activity of Spodoptera litura larvae}

Application of essential oils in various concentration level shows a dose-dependent increase in antifeedant activity of $S$. litura larvae (Table 3 ). Based on Table 3, the antifeedant activities of P1K4 and P1K5 are not significally different from each other. Also, P1K5 showed the highest percentage antifeedant activity $(79.3 \%)$. Antifeedants are defined as substances that can reduce consumption or feeding by an insect through a direct action on peripheral sensilla [23]. Antifeedant activity was induced by the chemical compounds in the essential oil that inhibitted appetite and of the larvae eventually leading to starvation and death [15]. The inhibitory chemical compounds have an effffect on the transmission of signals to the taste recep tors in insect gustatory sensilium [24]. Essential oil derived from $A$. calamus at $0.5-1 \%$ concentrations was found to significantly induce antifeedant activity and inhibition of growth third instar larvae of $S$. litura [8]. Asarone isolated from $A$. calamus also has potential as a growth inhibit and antifeedant of Peridroma saucia Hubner. asarone leads to 100,83 and $40 \%$ mortality in Nilaparvata lugens at concentrations of 1000, 500 and $250 \mathrm{ppm}$. In third instar larvae of Plutella xylostella, the mortality after asarone treatment is 83 and $50 \%$ at 1000 and $500 \mathrm{ppm}$. It is not effective against adult females of Myzus persicae and the third instar larvae $S$. litura even at $2000 \mathrm{ppm}$ [25].

\section{CONCLUSION}

A. calamus essential oil has potential as a biological insecticide against $S$. litura larvae with $\beta$-asarone as the major bioactive constituent. The application of $A$. calamus essential oil was to kill and reduce feeding activity in S. litura larvae by $92.5 \%$ and $79.3 \%$ respectively with LC50 of 586.96 ppm.

\section{ACKNOWLEDGMENT}




\section{REFERENCES}

1. Singh SP, Jalali SK (1997) Management of Spodoptera litura (Fabricius) (Lepidoptera: Noctuidae). In: Spodoptera litura in India. Proc. Natl. Sci. Forum Spodoptera litura, 2-4 Apr 1996.

2. Direktorat Perlindungan Tanaman Pangan (2012) Laporan Luas dan Serangan Hama Penyakit Tanaman Pangan di Indonesia. Direktorat Perlindungan Tanaman Pangan. Jakarta.

3. Jacobson M (1989) Botanical pesticides, past present and future. In: Insecticides of plant origin. (Ed. Arnason, J.T.). Proceeding of the American Chemical Society, Washington, D.C.: 1-10.

4. Adeyemi M, Hassan M (2010) The potential of secondary metabolites in plant material as deterents against insect pests: A review. Afr. J. Pure Appl. Chem. 4(11) : 243-246.

5. Rattan RS (2010) Mechanism of Action of Insecticidal Secondary Metabolites of Plant Origin. Crop Protect., 29(9): 913-920.

6. Hasan MU, Sagheer M, Ullah E et al (2006) Insecticidal activity of different doses of Acorus calamus oil against Trogoderma granarium (everts). J. Agriculture Science. 43 (1-2): 55-58.

7. Jiyavorranant T, Chanbang Y, Supyen D et al (2003) The Effect of Acorus calamus Linn ands Stemona tuberosa Lour. Extract on the Insect Pest, Pluttela xylostella (Linnaeus). Acta Hort. 597: 223-229.

8. Koul O (1987) Antifeedant and growth inhibitory effect of calamus oil and neem oil on Spodoptera litura under laboratory conditions. Phytoparasitica.15 (3): 169-180.

9. Koul O, Smirle MJ, Isman MB (1990) Asarones from Acorus calamus L. oil their effect on feeding behaviour and dietary dtilization Peridroma saucia. J. Chem. Ecol. 16(6) : 1911-1920.

10. Tariq RM, Naqvi SNH, Chundhary MI et al (2010) Importance and implemetation of esential oil of Pakistanian Acorus calamus Linn, as a biopesticide. Pak. J.Bot. 42(3) : 2043-2050.

11. Senthilkumar A, Venkatesalu V (2012) Larvicidal potential of Acorus calamus L. essential oil against filarial vector mosquito Cx. quinquefasciatus (Diptera: Culicidae). Asian Pacific Journal of Tropical Disease. 2 (4) : 324-326.

12. Adfa M, Fio L, Neva PM et al (2015) Termiticidal activity of Acorus calamus Linn. rhizomes and its main constituents against Coptotermes curvignathus Holmgren. Journal of Asia-Pacific Entomology. 18 (1) : 47-50.

13. Sahayaraj K (1998) Antifeedant effect of some Plant extracts on the Asian armyworm, Spodoptera litura (Fabricius)", Curent Science, 74(6): 532-526.

14. Bentley MD, Leonard DE, Stoddard WF et al (1984) Pyrrolizidinalkaloids as larval feeding deterrents for spruce bud worm, Choristoneura fumiferana (Lepidoptera: Tortricidae) Annals of the Entomological Society of America, 77(4): 393-397.

15. Arivoli S, Samuel T (2012) Antifeedant activity of plant extracts against Spodoptera litura (Fab.) (Lepidoptera: Noctuidae). American-Eurasian J. Agric. \& Environ. Sci., 12 (6): 764-768.

16. Abbot WS (1925) A method of computing the effectiveness of incesticide. J.Econ. Entomol. 18: 265-267.

17. Finney DJ (1971) Probit analysis. London, Cambridge University Press.

18. Boucias DG, Pendland JC (1998) Principles of insect pathology. London, Kluwer Academic Publisher.

19. Hung SY, Boucias DG (1996) Phenoloksidase activity in hemolymph of naïve and Beauveria bassiana-Infected Spodoptera exigua Larvae. Florida, Academic Press, Inc.

20. Oh MH, Houghton PJ, Whang WK et al (2004) Screening of Korean herbal medicines used to improve cognitive function for anti-cholinesterase activity. Phytomedicine 11 (6) : 544-548.

21. Matsumura F (1976) Toxicology of insecticides. New York, Plenum Press.

22. Sharma PR, Om PS, Bhaskar PS (2008) Effect of sweet flag rhizome oil (Acorus calamus) on hemogram and ultrastructure of hemocytes of the tobacco armyworm, Spodoptera litura (Lepidoptera: Noctuidae). Micron. 39 (5): 544-551.

23. Isman M (2002) Insect antifeedants: In pesticide outlook. Royal Soc.Chem.: 152-157.

24. Meyer JR (2006) Chemoreceptors. NC State University. Available online at http://www.cals.ncsu.edu/. Accessed: 2016.

25. Lee HK, Chan P, Young-Joon A (2002) Insecticidal activities of asarones identified in Acorus gramineus rhizome against Nilaparvata lugens (Homoptera: Elphacidae) and Plutella xylostella (Lepidoptera: Yponomeutoidae). Appl. Entomol. Zool. 37(3): 459-464. 